\title{
Extreme grape harvest data of Austria, Switzerland and France from A.D. 1523 to 2007 compared to corresponding instrumental/reconstructed temperature data and various documentary sources
}

\author{
C. Maurer • C. Hammerl • E. Koch • T. Hammerl • \\ E. Pokorny
}

Received: 16 March 2010 / Accepted: 13 January 2011 /Published online: 22 February 2011

(C) The Author(s) 2011. This article is published with open access at Springerlink.com

\begin{abstract}
The detection and quantification of extreme weather conditions in the past are important for correctly assessing the significance of today's extremes especially in the context of climate change. We specified extreme years by a synopsis of phenological data, temperature reconstructions and measurements and descriptive documentary sources starting in the 16th century. The spatial scale investigated is regional to interregional, covering Austria, Switzerland and northeastern France. Thus, we defined a list of 36 extreme years (1536-2007), where two or more of several parameters (grape harvest data and/or mean temperatures) available at that time exceeded the two-sigma threshold with regard to a reference period of 105 years. In Western Europe, there were extreme spring to early summer temperatures and/or exceptional phenological observations on all three locations in 1542, 1718, 1811, 1822, 2003, 2006 and 2007. As only grape harvest data are on hand, our phenological dates can only indicate anomalous temperature conditions during spring and early summer, i.e. mean temperatures which significantly correlate to these phenological records. In
\end{abstract}

\author{
C. Maurer • C. Hammerl • E. Koch $(\bowtie) \cdot$ T. Hammerl • \\ E. Pokorny \\ Zentralanstalt für Meteorologie und Geodynamik, \\ Hohe Warte 38, \\ 1190 Vienna, Austria \\ e-mail: elisabeth.koch@zamg.ac.at \\ C. Maurer \\ e-mail: christian.maurer@univie.ac.at \\ C. Hammerl \\ e-mail: christa.hammerl@zamg.ac.at \\ T. Hammerl \\ e-mail: a0800446@unet.univie.ac.at \\ E. Pokorny \\ e-mail: elfriede.pokorny@telekabel.at
}

addition to these data, we used independent documentary sources from the municipal archives of Retz, a town in Lower Austria, for affirming or amending these results.

\section{Introduction}

Periods with highly anomalous weather conditions-notably, temperature and/or precipitation extremes and their impacts on human health, ecosystems and economic systems-have attracted the attention of people at all times (e.g. Manley 1958; Pfister 1985, 1999; Landsteiner 1999; Pfister and Brázdil 2006; Luterbacher et al. 2004, 2007). But what are the objective criteria for calling a precipitation event or a temperature condition "extreme"? Human beings are prone to overestimate current or recent weather extremes and to relativize those which date further back in time. Besides, the lifespan of man is much too short to correctly assess the significance of all weather extremes experienced (Brázdil et al. 2010; Dobrovolný et al. 2010). Furthermore, perceptions alter in the course of time (e.g. increasing comfort, like housing or clothing). Therefore, purely descriptive, direct information about this topic must be evaluated with some caution and experience.

In order to solve this problem, (early) instrumental records of temperature and/or precipitation can be consulted. Regrettably, continuous instrumental measurements of temperature (e.g. Vienna-Hohe Warte from 1775 onwards) and precipitation (e.g. Vienna-Hohe Warte from 1841 onwards) do not go back beyond the 18th century. Besides, homogenizing early instrumental (temperature) measurements means facing extraordinary complexities (Manley 1974; Böhm et al. 2010), such as the effect of urban growth, changes in observation hours or in the 
immediate vicinity of the instruments, undetected instrumental errors, varying instrumentation and the results of imperfect or over-protected exposures.

What may help to detect extreme years is to tap the rich pool of non-descriptive proxies, especially biological data (Margary 1926; Lauscher 1978; Strestik and Verö 2000; Rutishauser et al. 2007; Sparks 2007; Jones et al. 2009), such as tree-ring density or-as in this paper-grape harvest data (GHD, see also Menzel 2005 or Garnier et al. 2010). Indeed, Rutishauser et al. (2008) point out that the temperature sensitivity of plant phenology alters in the course of centuries due to other long-term influences, like precipitation and snow covering. In addition, harvest data are always influenced by man-but if proxy data or reconstructions match the historical descriptions, the probability of having correctly determined an extreme event is high.

Extreme periods have been a research topic for many years. Jones and Briffa (2006), for example, tried to place the unusually cold year 1740 within a wider context. Briffa et al. (1992a, b, 1994) used tree-ring density records to reconstruct annually resolved series of average summer half-year temperatures and thereby found abnormal decades/years for northern Fennoscandia and North American regions. Büntgen et al. (2006) reconstructed common June to September temperature anomalies for the European Alps with the same kind of proxy data. Battipaglia et al. (2010) identified 44 summer extremes between 1550 and 2003 for Central Europe. They verified extremes based on tree-ring density from the higher elevations in the European Alps using documentary evidence from Switzerland, the Czech Republic and Central Europe. Just as tree-ring records are highly valuable if they stem from the northern tree line or high elevations (Frank and Esper 2005; Büntgen et al. 2007), GHD become valuable if, like in the Vienna region, vines grow in a climatic borderline zone where temperatures just permit vine growing (Maurer et al. 2009).

While most works on this topic focus on temperature reconstruction, we emphasized specifying extreme years by a synopsis of phenological data, instrumental temperature records, temperature reconstructions and descriptive historical sources on larger regional (Lower Austria) and interregional (Western Europe, i.e. Austria, Switzerland and north-eastern France) scales.

Three sub-periods are distinguishable for the Vienna region GHD and are used throughout the paper: 15231774 , the "historic" pre-instrumental period, when vintage data and reconstructed temperatures are available; 17751959, the "historic" instrumental period, when temperature measurements were made from 1775 onwards, and GHD are available up to 1879; and finally, 1960-2007, the "modern" instrumental period, when GHD (and, of course, measured temperatures) are on hand (see Table 1).

\section{Data}

Different sources were investigated to get information about wine and weather phenomena for Vienna, the neighbouring Klosterneuburg (Lower Austria) and Retz (Lower Austria). We worked exclusively with original primary or secondary sources in order to avoid mistakes, which may arise using secondary literature only. More detailed information about Vienna, Klosterneuburg and the corresponding sources is found in Maurer et al. (2009).

\subsection{Data for Klosterneuburg}

Relevant manuscript sources were studied at the archives of the Klosterneuburg monastery; the bulk of information used came from Manuscript StAK MS 121: Gedenkbuch und Weinchronik, a chronicle written by Josef Bittmann, Klosterneuburg, in 1880. It contains highly detailed information about vine growing and weather phenomena from 1540 to 1879 ; in our study, this period covers a major part of the so-called "historical" years (1523-1959).

Further, we read through Manuscript StAK MS 102 (a chronicle covering the time span 1577-1742, written in 1775, copying information from so-called "Schreibkalender"), Manuscript StAK MS 122/1 (contemporary chronicle, 1781-1813, reporting national and international events), Manuscript StAK MS 122/2 (continuation of 122/1, 18131833), Manuscript StAK D 73 (contemporary chronicle, 1796-1802 of the monastery of St. Dorothea in Vienna), StAK Box 221 (Wetter und Zufällechronik, compiled by Willibald Leyrer in 1789, with information for the time span 1322-1691).

Apart from general information about weather and climate, specific information was collected about vintage, wine quality and wine quantity.

GHD for the so-called "modern" period (1960-2007) are available only from 1970 to 2007 . They were compiled at Lehr- und Forschungszentrum für Wein- und Obstbau Klosterneuburg (Sommer 2008) from the original material (Schmuckenschlager 2007).

\subsection{Data for Vienna}

For the Vienna series, a standard work (Pribram et al. 1938) was used for the period 1523-1785 (Vienna-Buergerspital), which is a comprehensive, reliable, secondary source. Pribram evaluated primary sources at the municipal and provincial archives of Vienna. No relevant information is available for the period from 1786 to 1959 .

Data of the period 1960-1999 again are from the Lehr- und Forschungszentrum für Wein- und Obstbau Klosterneuburg (Sommer 2008) and were extracted from the original material (Klosterneuburg 2000). 
Table 1 List of parameters together with periods of availability, periods in use, periods of reference, reference mean and two-sigma value

\begin{tabular}{|c|c|c|c|c|c|c|c|c|}
\hline & Harv. Buerg./Vienna & Harv. Klosterneuburg & Harv. Swiss & Harv. Burg. & CEUT-AMJJ & T-AMJJ, Vie. & T-AMJJ, Basel\&Geneva & T-AMJJ, Stras. \\
\hline available & $1523-1749 \& 1960-1999$ & $1730-1879 \& 1970-2007$ & $1480-2006$ & $1370-2007$ & $1500-2007$ & $1775-2007$ & $1760-2007$ & $1801-2007$ \\
\hline used & $1523-1749$ \& 1960-1999 & $1730-1879 \& 1970-2007$ & 1523-2006 & 1523-2007 & $1523-1774$ & 1775-2007 & $1760-2007$ & 1801-2007 \\
\hline reference period & $1545-1649$ & $1775-1879$ & $1775-1879$ & $1775-1879$ & $1775-1879$ & $1775-1879$ & $1775-1879$ & 1801-1905 \\
\hline reference period mean [days of year, ${ }^{\circ} \mathrm{C}$ ] & 279.0 & 283.6 & 286.3 & 273.8 & 14.1 & 15.2 & 14.5 & 14.6 \\
\hline reference period two sigma value [days, ${ }^{\circ} \mathrm{C}$ ] & 17.0 & 17.5 & 18.5 & 18.3 & 1.9 & 2.2 & 1.7 & 1.8 \\
\hline
\end{tabular}

Parameters from left to right are harvest data of Buergerspital/Vienna, Klosterneuburg, the Swiss Plateau Region and Burgundy; the mean seasonal AMJJ-CEuT-temperature reconstruction and the mean seasonal surface AMJJ temperature at Vienna-Ho he Warte, at Basel\&Geneva and at Strasbourg

The publication Versuch (1803) is a compilation of various entries and is used only for the purpose of comparison. Though its reliability is questionable, it was consulted because it is often mentioned in the relevant literature. Additional information for Vienna is also found in the Chronicle d'Elvert (1861), which was written by the town chronicler of Iglau, and in Pilgram (1788), who compiled his work from a variety of contemporary sources, for the whole of Austria.

\subsection{Data for Retz}

Retz is located in the Weinviertel region in north-western Lower Austria. The town was granted the privilege of wine trading by Emperor Friedrich III in 1458. This privilege was the basis for the future wealth of Retz, where a huge and multi-storied underground system of wine cellars was built.

For Retz (Lower Austria) also, secondary sources, such as "Geschichtliche Aufzeichnungen der Stadt Retz" (Löschnig and Stefl 1935) and "Denkwürdigkeiten der Stadt Retz" (Puntschert 1894; first edition, 1870), were used, but compared to and verified with information from manuscript sources, such as the accounts of the Retz Buergerspital (see Fig. 1) and the "Gedenkbuch der Stadt Retz" (1896-1933) by Victor Apeldauer (1933).

The chronicle "Denkwürdigkeiten der Stadt Retz" (covering A.D. 1057 to 1866) was written by Josef Karl Puntschert, town clerk in Retz and its first archivist. He arranged the records of the Retz archives according to a new system and had therefore an excellent knowledge of the local historical sources when he compiled the volume "Denkwürdigkeiten der Stadt Retz" in 1870. He did not only describe weather phenomena but also stated prices (in $\mathrm{fl}=$ gulden) and quantity of wine per year [from 13561761, 1 emer (bucket) in Lower Austria $=58$ 1; from 17621875, 1 emer $=56.59$ 1; Sandgruber (1995)].

The "Geschichtliche Aufzeichnungen der Stadt Retz" (covering A.D. 1551 to 1933) is often mentioned in publications, but this compilation also relies on German sources and is thus not always relevant for the history of the Retz wine. A comparison with other sources is therefore indicated. Original contemporary sources are the comprehensive accounts of the Buergerspital in Retz. They contain detailed information-unfortunately with gaps-about wine grown in the Retz area for the period 1527-1860; thus, they serve as an excellent tool for verifying the later chronicles.

\subsection{Data for Burgundy and the Swiss Plateau Region}

GHD of Burgundy (1370-2007) and the Swiss Plateau Region (1480-2006) are derived from Chuine et al. (2004) and from Meier et al. (2007). In Burgundy (eastern France), these data were collected in parish and municipal archives. The grape variety "Pinot Noir" has been cultivated there since the 14th century, if not earlier. With regard to the Swiss Plateau Region (north-western Switzerland), GHD from 15 locations were incorporated in the time series.

\subsection{Temperature data}

Instrumental temperature data used for the stations ViennaHohe Warte (starting in 1775), Basel-Binningen (starting in 1760), Geneva-Cointrin (starting in 1760) and StrasbourgEntzheim (starting in 1801) are from the HISTALP data collection (Auer et al. 2007) in the bias-corrected version

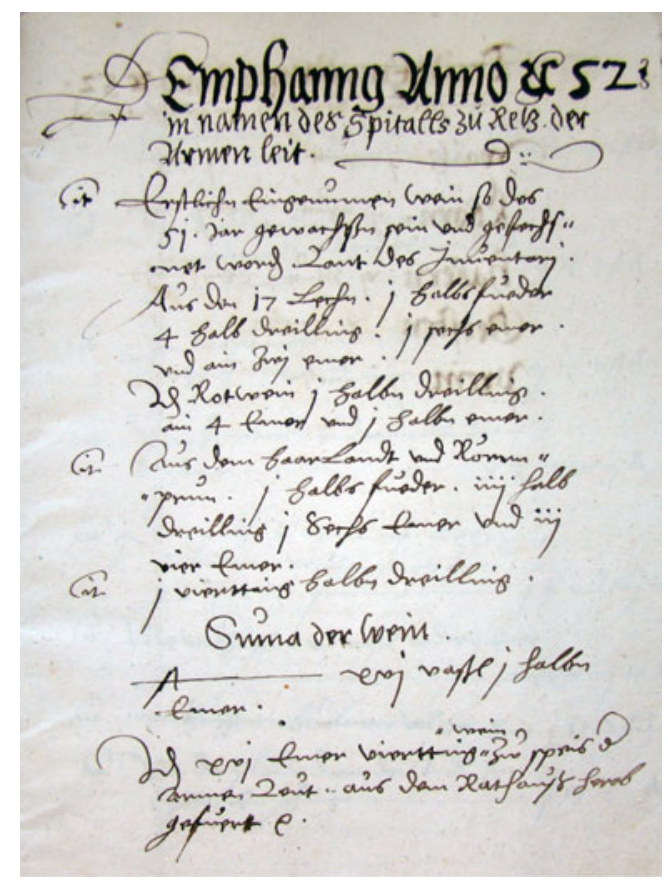

Fig. 1 Accounts of the Retz Buergerspital for the year 1552, original manuscript. Accounts of wine are described. Municipal archives, Retz (StARetz, Buergerspitalrechnungen 1552) 
2008 (Böhm et al. 2010). The monthly Central European temperature (CEuT, 1500-2007) reconstruction, developed by Dobrovolný et al. (2010) from documentary index series from Germany, Switzerland and the Czech Republic (15001854) and 11 instrumental temperature records (17602007), was used for the pre-instrumental period.

\section{Methods}

\subsection{The "historical" pre-instrumental period (1523-1774)}

First of all, we searched for extreme values in the time series of grape harvest in the pre-instrumental period 15231774 with reference to the long-term mean 1775-1879 in the case of the "historical" Klosterneuburg, Burgundy and Swiss Plateau data (see Table 1). This procedure was repeated for the 1545-1649 mean in the case of the "historical" Vienna-Buergerspital GHD (see Table 1). These two special 105-year reference periods were chosen due to the overlapping of the phenological records of Klosterneuburg and the homogenized temperature series at ViennaHohe Warte and due to nearly continuous GHD (Maurer et al. 2009). Guided by the mean temperature-GHD correlation analysis performed for the "historical" instrumental period (see Section 3.2), we used Dobrovolný et al. (2010) CEuT reconstruction in the form of April to July multimonth (AMJJ)-mean temperatures for the search of temperature extremes $(r=-0.61, p=0.01$, between ViennaBuergerspital GHD and AMJJ-mean temperature values for 1545-1649). The period 1775-1879 again constitutes the reference period for the CEuT series. An extreme value was defined as an event beyond the two-sigma threshold. In order to reduce the risk of mistakes resulting from possibly wrong entries in the chronicles or insufficiently reconstructed AMJJ temperatures, an extreme year in the preinstrumental period was defined by phenological data and reconstructed temperatures as one where at least two out of four parameters (harvest data of Burgundy, the Swiss Plateau Region and the Vienna region, AMJJ temperature reconstruction) turned out to be extremely anomalous (see Table 2 and Figs. 2, 3 and 4, extreme years 1536-1719). For the overlapping period of the Vienna-Buergerspital and Klosterneuburg GHD 1730-1749, a given year was classified as extreme only if both harvest data in addition to a third parameter (harvest date of Burgundy or of the Swiss Plateau Region or AMJJ temperature reconstruction) showed exceptional values. The addition of the Burgundy GHD (Chuine et al. 2004, see Table 1), the Swiss Plateau GHD (Meier et al. 2007, see Table 1) and Dobrovolný et al. (2010) CEuT reconstruction (see Table 1, reference period 1775-1879 in all cases) implies that the extreme years were traced interregionally. On the basis of the long Burgundy
GHD records (used for the purpose of this study from 1523 2007), we performed a Kolmogorov-Smirnov test to find a possible deviation from the assumed normal distribution. Since this test shows no statistically significant deviation, phenological data, like temperature data, are presumed to be normally distributed if the sample size is sufficiently large. As a consequence, applying a "2- $\sigma$-criterion" (as used by Chuine et al. 2004 and by Casty et al. 2005) for detecting extremes is justifiable.

\subsection{The "historical" instrumental period (1775-1959)}

For the "historical" instrumental period, we correlated different single- to multi-month temperature means of Vienna-Hohe Warte, Basel-Binningen, Geneva-Cointrin and Strasbourg-Entzheim to the GHD of Klosterneuburg, the Swiss Plateau Region and Burgundy. The mean temperatures of Basel-Binningen (located in the northeast of the Swiss Plateau Region) and Geneva-Cointrin (located in the southwest of the Swiss Plateau Region) were combined to arithmetic means before determining the correlations, in the following referred to as "Basel\&Geneva". For calculating the correlation coefficients, we used the period 1775-1879 (see Maurer et al. 2009) in the case of Klosterneuburg. Its GHD were correlated to Vienna mean temperatures. The same reference period was applied in the case of the correlation between Swiss GHD and Basel\&Geneva mean temperatures.

Table 2 List of years in the pre-instrumental period when two or more considered parameters showed extreme values

\begin{tabular}{|c|c|c|c|c|}
\hline & Harv. Buerg.-Vie. & Harv. Swiss & Harv. Burg. & CEUT-AMJJ \\
\hline 1536 & & & -2.3 & 2.7 \\
\hline 1540 & -2.4 & -3.5 & & 3.9 \\
\hline 1542 & 2.2 & 2.8 & 2.2 & \\
\hline 1559 & & -2.1 & -2.8 & \\
\hline 1571 & -2.6 & -2.2 & & \\
\hline 1590 & & -2.5 & -2.2 & \\
\hline 1599 & -2.4 & -2.4 & & \\
\hline 1603 & & -2.1 & & 2.0 \\
\hline 1611 & & -2.4 & & 2.2 \\
\hline 1616 & -2.5 & -3.2 & & 2.7 \\
\hline 1624 & & -2.2 & & 2.0 \\
\hline 1636 & & -2.1 & -2.7 & \\
\hline 1637 & & -2.4 & -2.9 & 2.3 \\
\hline 1638 & & -2.8 & -2.3 & 2.7 \\
\hline 1645 & & & -2.1 & 2.3 \\
\hline 1653 & -2.1 & & -2.1 & \\
\hline 1666 & -2.1 & & -2.2 & 2.9 \\
\hline 1675 & 2.9 & 2.7 & & \\
\hline 1684 & & & -2.7 & 2.2 \\
\hline 1718 & -2.4 & -3.4 & -2.7 & 2.0 \\
\hline 1719 & & -2.6 & -2.6 & \\
\hline
\end{tabular}

Figures depict sigma values with regard to the period 1545-1649 for the Vienna-Buergerspital GHD and with regard to the period 1775 1879 for the Swiss Plateau Region and Burgundy GHD as well as for the CEuT-AMJJ-temperature data. Grey shadings indicate positive harvest date extremes and negative temperature extremes 
Fig. 2 Comparison of unfiltered and Gauss-filtered (30-year window) GHD (days of year) per year for Burgundy.

Horizontal lines indicate corresponding two-sigma threshold with regard to the reference period $1775-1879$. Grey/black figures mark years with extreme early/late grape harvest as listed for the corresponding site in Tables 2 and 3

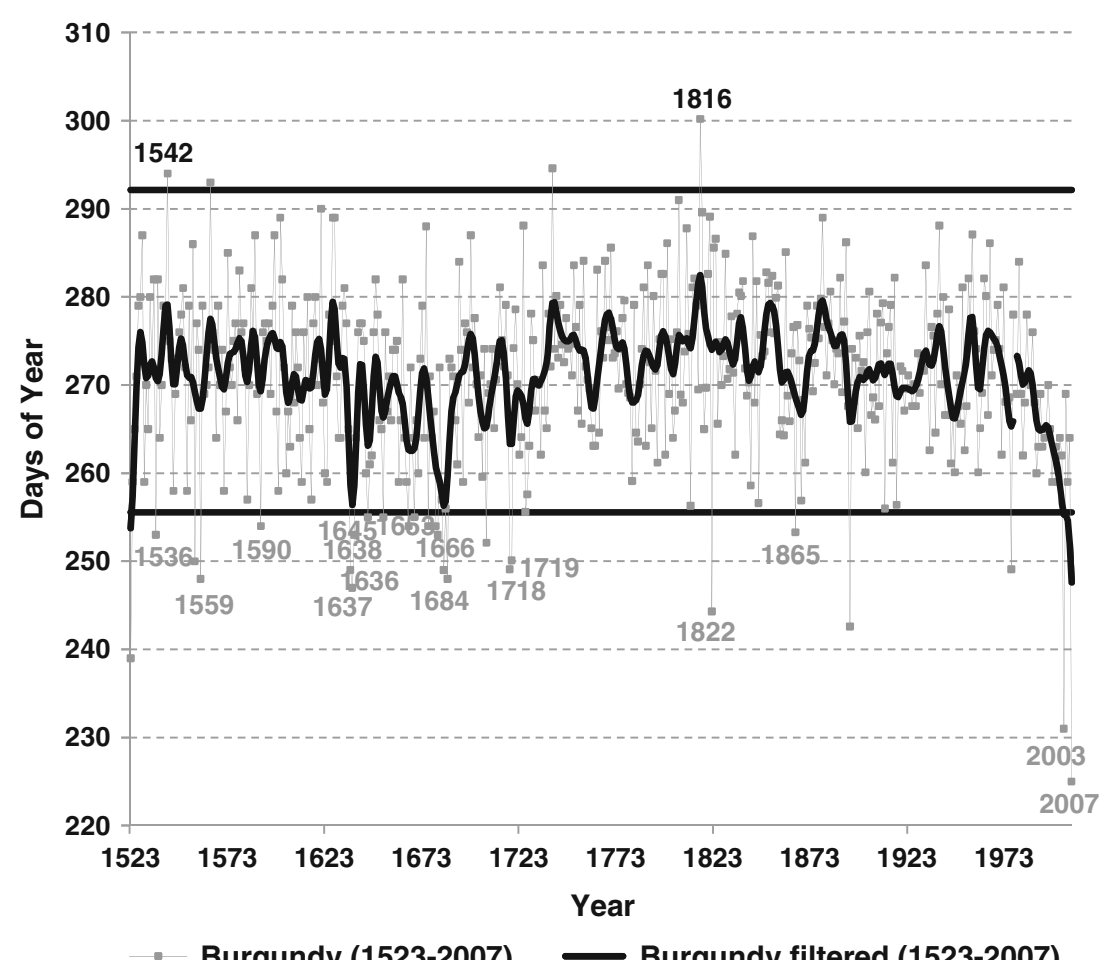

Burgundy (1523-2007) - Burgundy filtered (1523-2007)
The 1801-1905 period had to be taken in the case of the Burgundy GHD to Strasbourg mean temperature correlations. GHD were correlated to the annual mean temperature, the mean temperatures of April, May, June, July, April to July, May to June and May to July yielding statistically significant correlation coefficients between -0.25 and -0.83 ( $p=0.01$ or 0.05 , see also Maurer et al. 2009). Furthermore, we checked if the mean temperatures yielding the highest correlation coefficient for the Swiss Plateau Region $(r=-0.83$, $p=0.01)$ and for Burgundy $(r=-0.74, p=0.01)$ and the second highest correlation for the Vienna region $(r=-0.76, p=0.01)$, i.e. April to July mean temperatures, also exhibited extremes from the given reference mean 1775-1879; 1801-1905 had to be taken for Strasbourg (see also Table 1).
Fig. 3 Comparison of unfiltered and Gauss-filtered (30-year window) GHD (days of year) per year for the Swiss Plateau Region. Horizontal lines indicate corresponding two-sigma threshold with regard to the reference period 1775-1879. Grey/black figures mark years with extreme early/late grape harvest as listed for the corresponding site in Tables 2 and 3

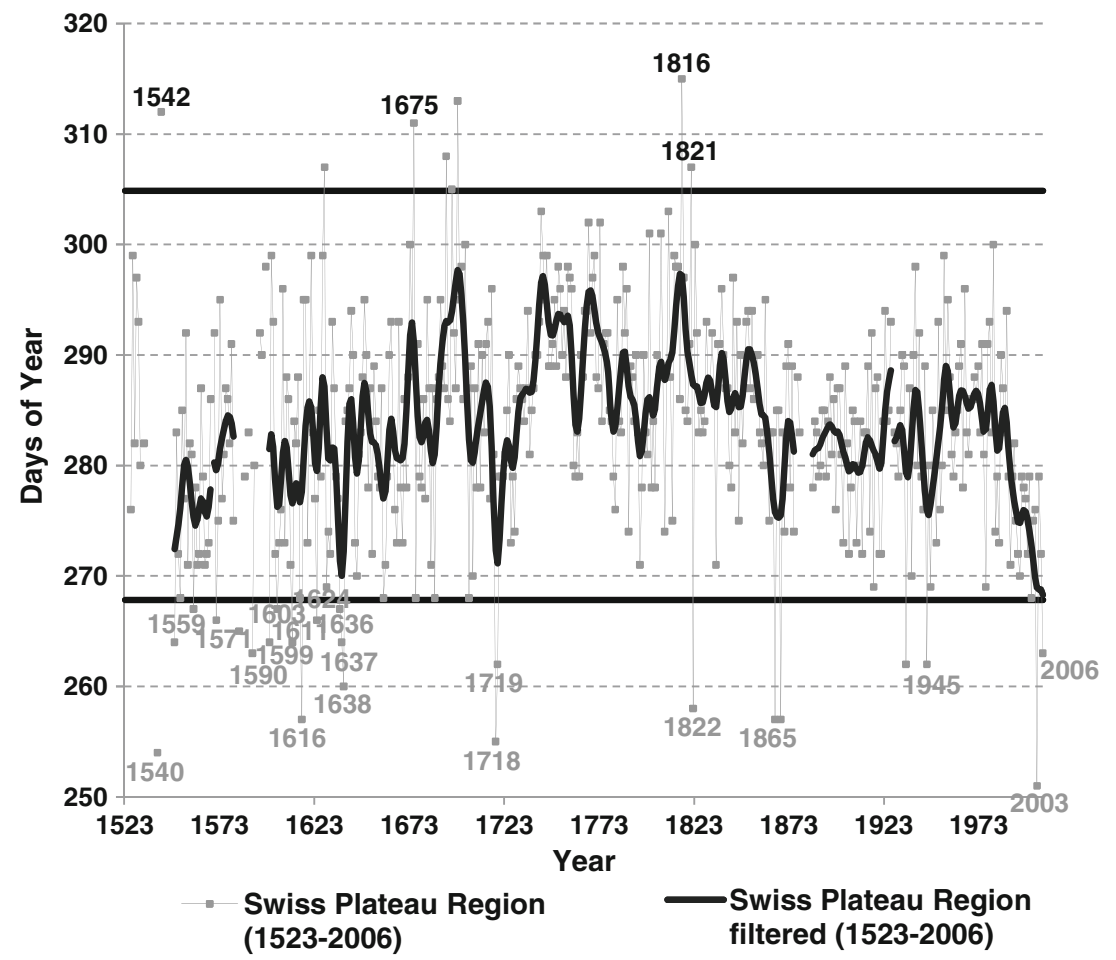


Fig. 4 Comparison of unfiltered and Gauss-filtered (30-year window) GHD (days of year) per year for Klosterneuburg and Buergerspital/Vienna. Horizontal lines indicate corresponding two-sigma threshold with regard to the reference periods 1775 1879, 1545-1649, respectively. Grey/black figures mark years with extreme early/late grape harvest as listed for the corresponding sites in Tables 2 and 3

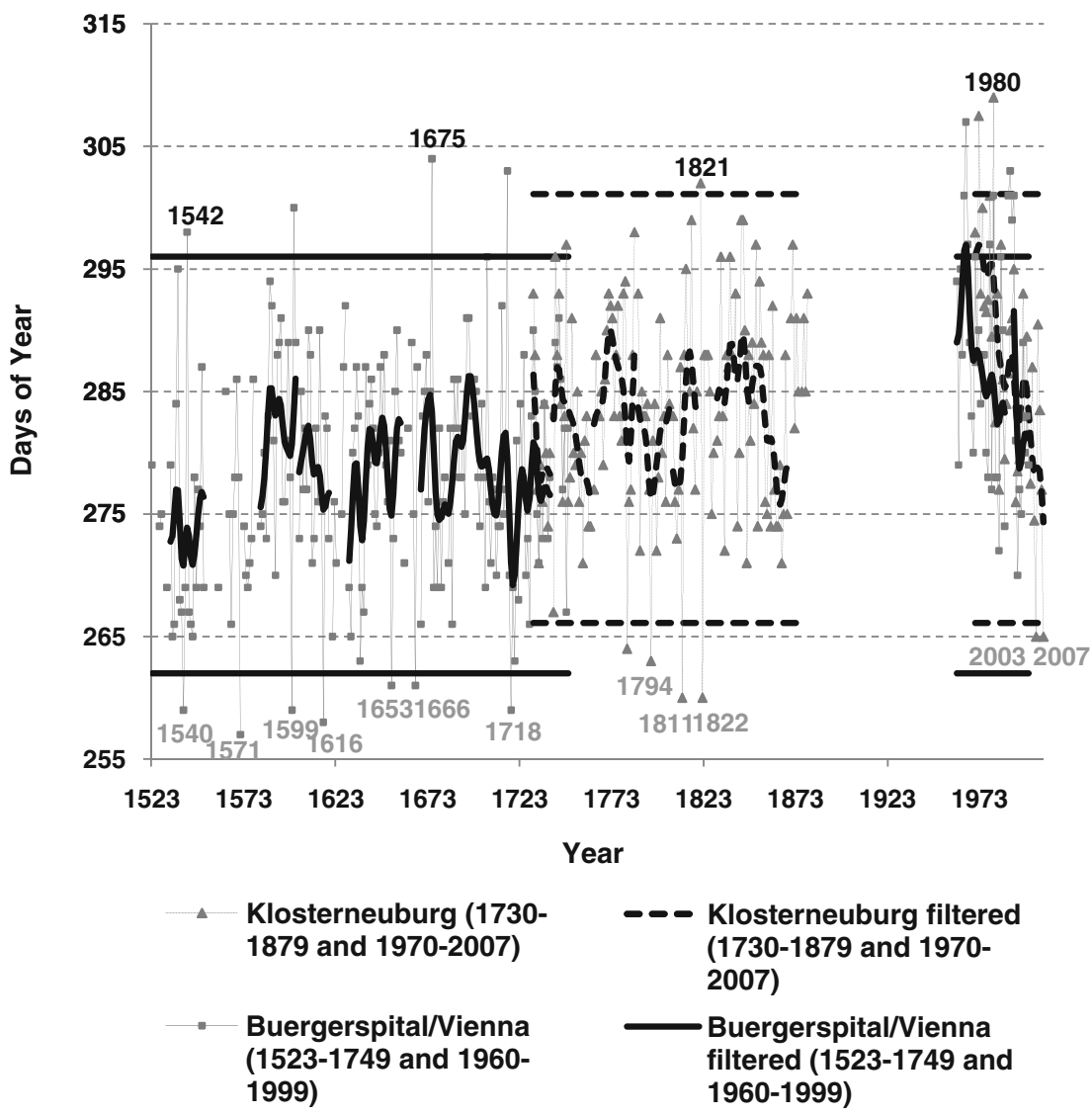

The first part of Table 3 contains extreme years in the "historical" instrumental period (1794-1947; see also Figs. 2, 3 and 4), where at least two out of six (out of five before 1801) parameters (phenological records or the abovementioned correlated mean temperatures) showed an extreme value.

\subsection{The "modern" period (1960-2007)}

The second part of Table 3 shows extreme years of the "modern" period (extreme years 1980-2007; see also Figs. 2, 3 and 4), where at least two out of six parameters (phenological records or the above-mentioned correlated

Table 3 List of years in the instrumental period when two or more considered parameters showed extreme values

\begin{tabular}{|c|c|c|c|c|c|c|c|}
\hline & Harv. Vie. & Harv. Klo. & Harv. Swiss & Harv. Burg. & T-AMJJ, Vie. & T-AMJJ, Basel\&Geneva & T-AMJJ, Stras. \\
\hline 1794 & / & -2.4 & & & 2.8 & 2.7 & / \\
\hline 1811 & / & -2.7 & & & 3.0 & 2.1 & 2.6 \\
\hline 1816 & / & & 3.1 & 2.9 & & -2.2 & -2.1 \\
\hline 1821 & / & 2.1 & 2.2 & & & & \\
\hline 1822 & / & -2.7 & -3.1 & -3.2 & & 2.1 & 2.2 \\
\hline 1837 & I & & & & -2.3 & & -2.2 \\
\hline 1865 & / & & -3.2 & -2.2 & & 2.6 & 3.0 \\
\hline 1945 & / & I & -2.6 & & & 2.7 & 2.4 \\
\hline 1947 & I & / & & & & 2.9 & 2.9 \\
\hline 1980 & 2.6 & 2.9 & & & & -2.1 & \\
\hline 2000 & / & & & & 2.1 & 2.0 & \\
\hline 2003 & I & -2.2 & -3.8 & -4.7 & 2.5 & 4.0 & 3.7 \\
\hline 2005 & I & & & & & 22 & 2.4 \\
\hline 2006 & I & & -2.5 & & 2.1 & 2.8 & 3.1 \\
\hline 2007 & / & -2.2 & / & -5.3 & 2.8 & 2.8 & 3.2 \\
\hline
\end{tabular}

Figures depict sigma values with regard to the period 1545-1649 for the Vienna GHD and with regard to the period 1775-1879 for the Klosterneuburg, the Swiss Plateau Region and Burgundy GHD as well as for Vienna-Hohe Warte and Basel\&Geneva temperature data. Strasbourg AMJJ-sigma values refer to the period 1801-1905. Grey shadings indicate positive harvest date extremes and negative temperature extremes. Slashes imply that no data are available 
mean temperatures) turned out to be anomalous. The reference periods (1645-1649, 1775-1879, 1801-1905) are the same as for the "historical" period. For the overlapping period of Vienna and Klosterneuburg GHD 1970-1999 again both harvest data had to be extreme apart from a third parameter in order to classify the respective year as outstanding.

\subsection{Comparison of extremes to other sources}

Tables 2 and 3 list 36 years according to the criteria mentioned. We compared the extreme phenological and mean temperature values of these years to each other and to descriptive entries in historical chronicles and manuscripts (Tables 4 and 5) as well as to recent results found by Brázdil and Kotyza (2000), Casty et al. (2005), Brázdil et al. (2008) and Etien et al. (2008). The chronicles of Retz (Puntschert 1894; Löschnig and Stefl 1935) and the accounts of the Retz Buergerspital, considered in addition to the records of Klosterneuburg and Vienna-Buergerspital, constitute a more or less independent possibility of comparison.

In order to take full advantage of all the descriptive information given by several chronicles and manuscripts in the "historical" period (pre-instrumental as well as instrumental), numeric quality and numeric quantity indices of wine for every year were correlated to the GHD records of Klosterneuburg and Vienna-Buergerspital (see Maurer et al. 2009). Since the resulting coefficients are statistically significant $(p=0.01$ or 0.05$)$ and negative throughout $(-0.46$ and -0.51 for quality and -0.23 and -0.30 for quantity), we concluded that very good/bad and very much/ little wine sometimes follows very early/late GHD, which in turn indicate to some extent extreme warm/cold mean temperature conditions. However, caution is appropriate, since the findings of Brázdil et al. (2008) for the Czech Republic reveal that differences in mean temperatures are often insignificant for neighbouring categories of wine quality ("excellent", "good", "average", "bad" etc.) or even do not exist.

Brázdil and Kotyza (2000) studied climate fluctuations in the Louny Region (Czech Republic) in the 15th to 17th centuries, based on books of accounts of the town of Louny. Casty et al. (2005) list of years (1500-2004) with extreme warm mean summer (JJA) and annual mean temperatures exceeding the two-sigma threshold of the 20th century mean, is based on reconstructions (1500 1900, henceforward, CRU temperatures) for the European Alps, using a combination of long instrumental station data and documentary evidence. Etien et al. (2008) list of extremely warm reconstructed AMJJAS mean temperatures, exceeding the 1.5 standard deviation of the centennial average, was compiled using $\delta^{18} O$ records of
Fontainebleau (France) latewood cellulose of both living trees and timber and the Burgundy grape harvest records in a bi-proxy reconstruction from A.D. 1596 to 2000. Brázdil et al. (2008) dealt with historical observations of the Czech lands before A.D. 1500 and in the 16th to 18th centuries.

\section{Results}

Tables 2 and 3 present extreme years selected according to the criteria mentioned in Chapter 3 for the pre-instrumental and instrumental periods. Tables 4 and 5 compare the information given in the literature used and the contemporary sources for the years listed in Tables 2 and 3.

As years with extremely advanced GHD, 1536, 1540, $1559,1571,1590,1599,1603,1611,1616,1624,1636,1637$, $1638,1645,1653,1666,1684,1718,1719,1794,1811,1822$, 1837, 1865, 1945, 1947, 2000, 2003, 2005, 2006 and 2007 were selected. Extremely delayed GHD were identified for $1542,1675,1816,1821$ and 1980. In the following, several special events are reported in greater detail:

The town chronicler of Jihlava (Czech Republic) said about the year 1540 in Vienna (d'Elvert 1861): "In Vienna and in other places many have poured out the wines because of a lack of barrels. Others have emptied the barrels with the old wine in the streets at night and filled them with the good, delicious new must. Some have not even been able to pick the grapes, because they could not buy any barrel."

For the year 1675, Leyrer (1789) noted: "Snow in May, ice, great damage in the vineyards - by bugs. This year the bugs have caused great damage in the vineyards almost everywhere, hence the government has ordered them to be collected, if possible. Sour and little wine." Puntschert (1894) recorded: "Snow at harvest time; the grapes had to be dug out of the snow."

For the year 1718, Puntschert (1894) reported: "Very good wine-within living memory no wine has grown as good, but medium vintage because of the great heat." The months of April and May in Lower Austria are described as warm and dry. The drought even resulted in a public order to pray for rain (Sammlung 1719). In the summer, an unbearable, long-lasting heat wave prevailed. With the exception of grapes, field crops turned out badly. People had to fight forest fires, and wells, rivers and lakes dried out (Versuch 1803).

For the year 1794, Manuscript MS 121 (1880) reads: "This year there is no winter, no snow and no coldness. On 15 May vines are flowering."

According to the entries in MS 121 and MS 122-2, 1821, very wet conditions dominated the vegetation period in nearly all European countries, leading to floods which destroyed large parts of the harvest. Cold winds, morning frost and snowfall are reported in some parts of Austria on 
Table 4 Comparison of the extreme years of the "historical" pre-instrumental period as listed in Table 2 to diverse documentary sources as well as to extremes defined by Casty et al. (2005) and Etien et al. (2008)

\begin{tabular}{|c|c|c|c|c|c|c|c|c|c|}
\hline & $\begin{array}{l}\text { Vienna- } \\
\text { Buergerspital } \\
\text { Pribram et al. } \\
(1938) \\
\text { Fee for lease of } \\
\text { vineyard per } \\
\text { bucket must in } \\
\text { kr. }\end{array}$ & $\begin{array}{l}\text { Retz } \\
\text { Buerger- } \\
\text { spital }\end{array}$ & $\begin{array}{l}\text { Puntschert } \\
\text { (1894) }\end{array}$ & $\begin{array}{l}\text { Pilgram } \\
\text { (1788) }\end{array}$ & $\begin{array}{l}\text { Leyrer } \\
\text { (1789) }\end{array}$ & $\begin{array}{l}\text { d'Elvert } \\
\text { (1861) }\end{array}$ & $\begin{array}{l}\text { Löschnig } \\
\text { and Stefl } \\
\text { (1935) }\end{array}$ & $\begin{array}{l}\text { Casty } \\
\text { et al. } \\
\text { (2005) }\end{array}$ & $\begin{array}{l}\text { Etien } \\
\text { et al. } \\
\text { (2008) }\end{array}$ \\
\hline 1536 & kr. 90.- & & & & & & & & \\
\hline 1540 & $\begin{array}{l}\text { kr. 52.50; good } \\
\text { wine }\end{array}$ & & $\begin{array}{l}\text { very hot and dry } \\
\text { summer; } \\
\text { very early } \\
\text { harvest; very } \\
\text { good and strong } \\
\text { wine }\end{array}$ & $\begin{array}{l}\text { wine very } \\
\text { good; } \\
\text { hot and dry } \\
\text { summer }\end{array}$ & & $\begin{array}{c}\text { big } \\
\text { amount; } \\
\text { ten } \\
\text { buckets } \\
\text { wine at } \\
\text { Vienna } \\
\text { for } 2 \mathrm{fl} .\end{array}$ & & $x$ & \\
\hline 1542 & kr. 90.- & & $\begin{array}{l}\text { very dry } \\
\text { summer; } \\
\text { bad wine year }\end{array}$ & & & & & & \\
\hline 1559 & $\begin{array}{l}\text { kr. 120.-; big } \\
\text { price rise }\end{array}$ & $\begin{array}{l}329 \\
\text { buckets }\end{array}$ & $\begin{array}{l}\text { bad wine year, } \\
\text { because of } \\
\text { frost; big price } \\
\text { rise }\end{array}$ & $\begin{array}{l}\text { very small } \\
\text { harvest } \\
\text { because of } \\
\text { frost }\end{array}$ & & & $\begin{array}{l}\text { cold, wet } \\
\text { year; little } \\
\text { and sour } \\
\text { wine }\end{array}$ & & \\
\hline 1571 & kr. 135.- & $\begin{array}{l}147 \\
\text { buckets }\end{array}$ & & & & & $\begin{array}{l}\text { little and sour } \\
\text { wine }\end{array}$ & & \\
\hline 1590 & kr. 135.- & & & & & & $\begin{array}{l}\text { very hot } \\
\text { summer; } \\
\text { little, but very } \\
\text { good wine, } \\
\text { exceptional } \\
\text { during the } \\
\text { past } 100 \\
\text { years }\end{array}$ & & \\
\hline 1599 & $\begin{array}{l}\text { kr. 120,-; good } \\
\text { wine }\end{array}$ & & good wine & $\begin{array}{l}\text { very good } \\
\text { wine }\end{array}$ & & & $\begin{array}{l}\text { early, warm } \\
\text { spring; very } \\
\text { much and } \\
\text { good wine }\end{array}$ & & \\
\hline 1603 & kr. 150.- & & & & & & $\begin{array}{l}\text { very dry, but } \\
\text { fertile } \\
\text { summer; } \\
\text { very much } \\
\text { and good } \\
\text { wine }\end{array}$ & & \\
\hline 1611 & kr. 127.50 & & & & & & $\begin{array}{l}\text { wet summer, } \\
\text { cold autumn; } \\
\text { pretty much } \\
\text { wine, but bad } \\
\text { quality }\end{array}$ & & \\
\hline 1616 & $\begin{array}{l}\text { kr.165,-; damage } \\
\text { by showers }\end{array}$ & & $\begin{array}{l}\text { damage by } \\
\text { showers }\end{array}$ & & $\begin{array}{l}\text { extensive } \\
\text { shower, } \\
\text { ample } \\
\text { rainfall }\end{array}$ & & $\begin{array}{l}\text { summer very } \\
\text { hot; little, but } \\
\text { very good } \\
\text { wine }\end{array}$ & & \\
\hline 1624 & & & & & & & $\begin{array}{l}\text { hot summer; } \\
\text { little, but } \\
\text { good wine }\end{array}$ & & \\
\hline 1636 & kr. 195.- & & & & & & $\begin{array}{l}\text { good and } \\
\text { pretty much } \\
\text { wine }\end{array}$ & & $x$ \\
\hline 1637 & $\begin{array}{l}\text { kr. } 180,-; \text { ruined } \\
\text { by bugs }\end{array}$ & & & $\begin{array}{l}\text { bugs in the } \\
\text { vineyards }\end{array}$ & & & $\begin{array}{l}\text { much and } \\
\text { good wine; } \\
\text { many } \\
\text { vineyards not } \\
\text { cultivated }\end{array}$ & & $x$ \\
\hline 1638 & kr.105.- & $\begin{array}{l}33 \\
\text { buckets }\end{array}$ & droughty year & & & & $\begin{array}{l}\text { wet flowering } \\
\text { period; little } \\
\text { wine, but } \\
\text { very good } \\
\text { and very } \\
\text { expensive; } \\
\text { heavy wine }\end{array}$ & & \\
\hline 1645 & $\begin{array}{l}\text { kr. 135,-; bad } \\
\text { wine }\end{array}$ & & bad wine & bad wine & & & $\begin{array}{l}\text { good and } \\
\text { fertile year; } \\
\text { much and } \\
\text { good wine }\end{array}$ & & \\
\hline 1653 & kr. 150,- & $\begin{array}{l}87 \\
\text { buckets }\end{array}$ & & & & & $\begin{array}{l}\text { much and } \\
\text { good wine }\end{array}$ & & \\
\hline
\end{tabular}




\begin{tabular}{|c|c|c|c|c|c|c|c|c|}
\hline 1666 & kr. 180,- & $\begin{array}{l}51 \\
\text { buckets }\end{array}$ & & $\begin{array}{l}\text { cold at the } \\
\text { end of April; } \\
\text { summer } \\
\text { very dry }\end{array}$ & $\begin{array}{l}\text { cold May } \\
\text { with } \\
\text { hoarfrost }\end{array}$ & $\begin{array}{l}\text { pretty much } \\
\text { and very } \\
\text { good wine }\end{array}$ & & \\
\hline 1675 & $\begin{array}{l}\text { kr. 225,-; little } \\
\text { and bad wine }\end{array}$ & $\begin{array}{l}21 \\
\text { buckets }\end{array}$ & $\begin{array}{l}\text { little and bad } \\
\text { wine; } 1 \text { bucket = } \\
1-3 \text { fl. }\end{array}$ & $\begin{array}{l}\text { little and bad } \\
\text { wine }\end{array}$ & $\begin{array}{l}\text { damage by } \\
\text { bugs; } \\
\text { little and } \\
\text { sour wine }\end{array}$ & $\begin{array}{l}\text { little and sour } \\
\text { wine; very } \\
\text { cold May } \\
\text { with snow } \\
\text { and frost }\end{array}$ & $X$ & \\
\hline 1684 & $\begin{array}{l}\text { kr. 195,-; little } \\
\text { and bad wine }\end{array}$ & $\begin{array}{l}60 \\
\text { buckets }\end{array}$ & $\begin{array}{l}\text { bad wine year, } \\
\text { little wine }\end{array}$ & $\begin{array}{l}\text { little and bad } \\
\text { wine }\end{array}$ & rot & $\begin{array}{l}\text { heat and } \\
\text { drought; } \\
\text { early harvest; } \\
\text { pretty much } \\
\text { and very } \\
\text { good wine }\end{array}$ & & \\
\hline 1718 & $\begin{array}{l}\text { kr. } 285,-; \text { very } \\
\text { good, medium } \\
\text { harvest, because } \\
\text { of great heat }\end{array}$ & $\begin{array}{l}80 \\
\text { buckets }\end{array}$ & $\begin{array}{l}\text { early grape } \\
\text { harvest; very } \\
\text { good wine, } \\
\text { medium harvest, } \\
\text { because of } \\
\text { great heat; } \\
1 \text { bucket = } 3 \mathrm{fl} .\end{array}$ & $\begin{array}{l}\text { big drought; } \\
\text { very good } \\
\text { wine }\end{array}$ & & $\begin{array}{l}\text { terrible heat, } \\
9 \text { months dry } \\
\text { weather; } \\
\text { early grape } \\
\text { harvest; } \\
\text { much and } \\
\text { very good } \\
\text { wine }\end{array}$ & $X$ & $x$ \\
\hline 1719 & $\begin{array}{l}\text { kr. 195,-; good } \\
\text { and much wine, } \\
\text { but extensive rot }\end{array}$ & $\begin{array}{l}217 \\
\text { buckets }\end{array}$ & $\begin{array}{l}\text { good and much } \\
\text { wine; large- } \\
\text { scale rot; } 1 \\
\text { bucket = } 1.5 \mathrm{fl} \text {. }\end{array}$ & $\begin{array}{l}\text { very good } \\
\text { wine }\end{array}$ & & $\begin{array}{l}\text { very much } \\
\text { and good } \\
\text { wine }\end{array}$ & & $x$ \\
\hline
\end{tabular}

1 Gulden (fl.) $=60$ Kreuzer (kr.) according to the Coinage Code of the Austrian duchies of 1524

June 20. As a consequence, the refectory of the Klosterneuburg monastery had to be heated on June 24 and 25. MS 122-2 speaks of a "late grape harvest, the saddest in Austria within living memory" caused by the late coldness and the prolonged wetness.

\section{Discussion and conclusion}

5.1 Importance of the Vienna vintage data in the context of historical climatology

Our vintage data belong to the category of so-called "indirect" data (Brázdil et al. 2010) which refer to physically based events linked to weather and climate. These bio-physical data are in general more likely to cover the low-frequency component of climate than "direct" documentary evidence, e.g. descriptions of weather conditions, because no transformations have to be made from the raw data to index series. As a consequence, Brázdil et al. (2010) state that, e.g. phenophases may improve the reconstruction skill when used in combination with documentary index data. However, slow systematic changes in GHD (Garnier et al. 2010) due to technical improvements in viticulture, the evolution of the consumers' taste, changes in grape varieties or the development of road infrastructures are clearly visible in the last part of the Vienna region GHD time series at the end of the 20th century. This implies that trends on a century scale in temperature reconstructions based on GHD have to be interpreted with great caution (see also Section 5.5).

\subsection{Extreme years on different scales}

We found extreme years on a greater regional (Lower Austria) and on an interregional (Austria, Switzerland and north-eastern France) scale. In 1542, 1718, 1822 and 2003, extreme phenological events occurred at all three vinegrowing sites, but outstanding temperature conditions for Central Europe or in all the corresponding towns (Vienna, Basel\&Geneva and Strasbourg) can be confirmed only for 1718 and 2003. The harvest was remarkably advanced on all three locations (Vienna/Klosterneuburg, Burgundy and the Swiss Plateau Region), although there is quite a big geographical distance between the Swiss Plateau Region and Burgundy on the one hand and Vienna/Klosterneuburg on the other. The correlation coefficients between, e.g. Vienna-Buergerspital and Burgundy $(r=0.46)$, ViennaBuergerspital and the Swiss Plateau Region $(r=0.65)$ and Burgundy and the Swiss Plateau Region $(r=0.79, p=0.01$ in all three cases), confirm that this analogy is not a coincidence. However, bearing the geographical locations in mind, one will understand that the data of Burgundy and the Swiss Plateau Region show the highest correlation, whereas the Vienna and Burgundy data reveal the lowest correlation. The highly significant correlation of GHD all over Central and Western Europe is referred to by Le Roy Ladurie (1977) and Rutishauser et al. (2007). Le Roy Ladurie (1977) attributes this to a large-scale effect of temperature regimes.

The years 1540, 1571, 1599, 1616, 1653, 1666, 1675, 1794, 1811, 1821, 1837, 1980, 2000, 2006 and 2007 show extremes in the Vienna region (GHD or AMJJ-mean temperature) and at 
Table 5 Comparison of the extreme years of the "historical" instrumental period as listed in Table 3 to diverse documentary sources as well as to extremes defined by Casty et al. (2005) and Etien et al. (2008)

\begin{tabular}{|c|c|c|c|c|c|}
\hline & $\begin{array}{l}\text { Puntschert } \\
\text { (1894) }\end{array}$ & $\begin{array}{l}\text { MS 121 } \\
(1880)\end{array}$ & $\begin{array}{l}\text { Löschnig } \\
\text { and Stefl } \\
\text { (1935) }\end{array}$ & $\begin{array}{l}\text { Casty } \\
\text { et al. } \\
(2005)\end{array}$ & $\begin{array}{l}\text { Etien } \\
\text { et al. } \\
\text { (2008) }\end{array}$ \\
\hline 1794 & $\begin{array}{l}\text { very good } \\
\text { wine; } 1 \\
\text { bucket = } 2 \mathrm{fl} \text {. }\end{array}$ & $\begin{array}{l}\text { always } \\
\text { warm; } \\
\text { good } \\
\text { harvest, } \\
\text { good wine; } 1 \\
\text { bucket = } 4 \mathrm{fl} \text {. }\end{array}$ & $\begin{array}{l}\text { at the } \\
\text { end of } \\
\text { March all } \\
\text { plants } \\
\text { and trees } \\
\text { turned } \\
\text { green; } \\
\text { excellent } \\
\text { wine }\end{array}$ & & \\
\hline 1811 & $\begin{array}{l}\text { excellent } \\
\text { wine; "extra- } \\
\text { wine" } 80-85 \\
\text { fl.; in August } \\
\text { "extra- } \\
\text { wine"185 fl.; } \\
\text { red wine } 190 \\
\text { fl.; vinegar } 60 \\
\text { fl. }\end{array}$ & $\begin{array}{l}\text { early spring } \\
\text { proved to be } \\
\text { rather cold; } \\
\text { September } \\
\text { big heat; } \\
\text { excellent } \\
\text { harvest and } \\
\text { wine; } 1 \\
\text { bucket = } 20 \\
\text { fl. }\end{array}$ & $\begin{array}{l}\text { "Famous, } \\
\text { brilliant, } \\
\text { first class } \\
\text { wine } \\
\text { year. } \\
\text { Very } \\
\text { much and } \\
\text { excellent } \\
\text { wine, as } \\
\text { in 1783." }\end{array}$ & $X$ & $x$ \\
\hline 1816 & $\begin{array}{l}\text { wine of } \\
\text { medium } \\
\text { grade; } 1 \\
\text { bucket = } 60 \\
\text { fl.; „extra- } \\
\text { wine“ } 70 \mathrm{fl} . ; \\
1812 \text { er wine } \\
40 \mathrm{fl} \text {. }\end{array}$ & $\begin{array}{l}\text { July and } \\
\text { August } \\
\text { warm; } \\
\text { September } \\
\text { and October } \\
\text { rainy and } \\
\text { cold; small } \\
\text { harvest and } \\
\text { sour wine; } \\
1 \text { bucket = } \\
32 \mathrm{fl} \text {. }\end{array}$ & $\begin{array}{l}\text { frosty } \\
\text { April with } \\
\text { snow at } \\
\text { Easter; } \\
\text { much rain } \\
\text { in the } \\
\text { following } \\
\text { months; } \\
\text { bad } \\
\text { harvest; } \\
\text { little and } \\
\text { sour wine }\end{array}$ & $X$ & \\
\hline 1821 & $\begin{array}{l}\text { bad wine; } 1 \\
\text { bucket = } 12 \text { fl. }\end{array}$ & $\begin{array}{l}\text { small } \\
\text { harvest and } \\
\text { sour wine; } 1 \\
\text { grape } \\
\text { pannier = } 3 \\
\text { fl. }\end{array}$ & $\begin{array}{l}\text { wine } \\
\text { damage } \\
\text { caused } \\
\text { by } \\
\text { worms; } \\
\text { small } \\
\text { harvest; } \\
\text { little wine, } \\
\text { bad } \\
\text { quality }\end{array}$ & & \\
\hline 1822 & $\begin{array}{l}\text { excellent but } \\
\text { medium } \\
\text { harvest; } 1 \\
\text { bucket (wine) } \\
\text { = } 32 \mathrm{fl} \text {; } \\
\text { vinegar } 23 \mathrm{fl} .\end{array}$ & $\begin{array}{l}\text { small } \\
\text { harvest and } \\
\text { excellent } \\
\text { wine; } 1 \\
\text { bucket }=30 \text {, } \\
35 \text { and } 40 \text { fl. }\end{array}$ & $\begin{array}{l}\text { hot } \\
\text { summer; } \\
\text { much and } \\
\text { very good } \\
\text { wine, as } \\
\text { in } 1811\end{array}$ & $X$ & $X$ \\
\hline 1837 & $\begin{array}{l}\text { bad harvest; } \\
1 \text { bucket = } 8 \\
\text { fl. } 30 \mathrm{kr} \text {. }\end{array}$ & $\begin{array}{l}\text { always rainy } \\
\text { and cold } \\
\text { until } 5 \\
\text { August, after } \\
\text { that sunny } \\
\text { and warm; } \\
\text { small } \\
\text { harvest and } \\
\text { sour wine; } 1 \\
\text { bucket = } 2 \text { fl. } \\
\text { ("Convention } \\
\text { Currency") }\end{array}$ & $\begin{array}{l}\text { little and } \\
\text { bad wine; } \\
\text { regional } \\
\text { bad } \\
\text { harvest }\end{array}$ & & \\
\hline 1865 & $\begin{array}{l}\text { little harvest, } \\
\text { good wine; } \\
\text { very dry year; } \\
1 \text { bucket = } \\
10-12 \text { fl. }\end{array}$ & $\begin{array}{l}\text { rainy and } \\
\text { cold July; } \\
\text { September } \\
\text { sunny; small } \\
\text { harvest; } 1 \\
\text { bucket = } 11 \\
\text { and } 12 \text { fl. } \\
\text { ("Convention } \\
\text { Currency") }\end{array}$ & $\begin{array}{l}\text { pretty } \\
\text { much } \\
\text { wine of } \\
\text { excellent } \\
\text { quality, } \\
\text { one of } \\
\text { the most } \\
\text { excellent } \\
\text { wines of } \\
\text { the } \\
\text { century }\end{array}$ & & \\
\hline
\end{tabular}

1 Gulden (fl.) $=60$ Kreuzer (kr.) according to the Coinage Code of the Austrian duchies of 1524. After the national bankruptcy in 1811, the "Vienna Currency" (W. W.) was introduced, followed by the "Convention Currency" in 1819 least in one of the other time series (Burgundy GHD, Swiss Plateau GHD, CEuT-AMJJ temperatures, Basel\&Geneva temperatures, Strasbourg temperatures) where again 1540 (see Glaser et al. 1999 for a detailed description of that year), 1616, 1666, 1794, 1811, 1837, 1980, 2000, 2006 and 2007 are confirmed with regard to temperature in the CEuT series or at least in one of the corresponding towns. For 1811 and 2006, we even could find exceptional mean temperatures in all three towns. So, all the above years can also be considered extreme on an interregional scale. The years of 1794, 1811 and 1980 experienced exceptional phenological data only in the Vienna region, but in some French and/or Swiss vineyards, extreme grape harvest data could have been observed because of the detectable, remarkable temperature conditions. The years 1837 and 2000 are free from any outstanding phenological extremes; yet, these are imaginable for some places owing to the temperature information available.

In 1590, 1603, 1624, 1636, 1637, 1638, 1719 and 1865, the descriptive entries of the Retz chronicles fit phenological conditions in Burgundy and/or the Swiss Plateau Region. So, some of these years might also have been extreme on an interregional scale. But as stated in Sections 1 and 3.4, one has to be careful when judging on the basis of (purely descriptive) information about wine quality and quantity. For the year 1865, which is within the instrumental period, no extreme temperature is detectable at ViennaHohe Warte, despite the wine in Retz being praised as one of the most excellent of the century.

In 1611, a wet summer in Retz seems to be responsible for a grape harvest of minor quality. The years of 1559 and 1816 seem to be quite contradictory on an interregional scale.

The years of 1945, 1947 and 2005 seem to have been outstanding at least in north-eastern France and/or in northwestern Switzerland.

Looking at extremes defined as values greater than the two-sigma threshold, one finds remarkable results at the turn of the 20th to the 21th centuries, the "modern" period. All temperature extremes are positive with regard to the period mean 1775-1879/1801-1905 and all extreme yearswith the exception of one-selected according to the criteria mentioned in Chapter 3 occur after 1999. The year of 2003 features extreme values: never before had Burgundy (42.8 days advanced with regard to the $1775-1879$ period) and the Swiss Plateau Region (35.3 days advanced with regard to the 1775-1879 period) experienced such an early harvest date. All three available phenological data and all three considered mean temperatures showed extreme values. The year 2007, the last year in Table 3, exhibits three positive temperature extremes and a remarkable negative grape harvest extreme in Burgundy of nearly 50 days $(5.3 \sigma)$. 
Outstanding results are that three out of only 6 years with negative temperature extremes and/or positive grape harvest extremes cluster in the period 1816 to 1837 . Besides, there was not a single extreme negative AMJJ temperature in the CEuT series from 1523 until 1774, and not a single negative or positive extreme AMJJ temperature at Vienna-Hohe Warte can be found between 1874 and 1983. Also, the phenological and temperature extremes themselves have the same sign (+/-) during one considered year and the opposite sign with respect to each other.

\subsection{Comparison to documentary evidence of the Czech Republic}

Concerning our list of extreme years, Brázdil and Kotyza (2000) note for 1540 that the beginning of the harvest, as well as the harvest of barley, oats and peas in particular, occurred earliest that year with regard to the whole period under study (1517-1622). In the year 1542, which appears as a cold extreme in our list, ice could be found on stagnant water even on June 7, following a very cold May. In 1571, in contrast to GHD considered in the present paper, hop picking took place latest in mid-October with regard to the whole period 15171622. The year 1599 is marked by a very early grape harvest in the Louny region in mid-September, and wages were paid for clearing bilge between the wheels at one Louny mill, which could have been the consequence of a dry period with a low water level. Several heavy downpours in July and August of 1603, which apparently affected the grain, cannot be found in the recordings for Retz.

In the year 1616, the beginning of the rye harvest was the earliest, as was the end of the harvest with regard to the period 1517-1622. The reason may have been an extraordinary drought starting already in April and lasting throughout the summer, which is also described as hot. As a consequence, rivers dried up, and a water-level mark was added on the so-called "hunger stone" on the left bank of the river Elbe at Decin. Winter grains yielded average harvests, but spring cereals and other field crops shrivelled. Grass withered, and the aftermath was not mown. The vintage at Louny was completed in mid-October, yielding good, but not much, wine. According to the information in Brázdil et al. (2008), in 1616, the harvest in the Bohemian town Louny took place on September 8, after a very warm and dry summer, thus being the earliest recorded one in this region in the 17th century. This recording fits very well our findings for the considered year (see also the results from Brázdil and Kotyza 2000 above).

In contrast, the 2 years with the latest harvest data of the century, namely 1608 and 1619 , do not appear in our list of extremes. The entry in the Retz chronicle by Löschnig and Stefl (1935) for 1614 contradicts the description of abundant wine in Louny, which led to a halt in beer production in Litomerice, but both Retz chronicles confirm that 1627 was a disastrous year for winegrowers. However, as we do not have a single extreme anomaly for the 2 years 1614 and 1627 in our records, they do not appear in Table 2 or 4. Damage due to late frost in May 1666 in various villages in southern Moravia is reflected in Pilgram (1788, see Table 4) but cannot be proven for Retz.

For 1816, Brázdil et al. (2008) found the latest grape harvest date in the Znojmo GHD series which covers almost the whole 19th century. The year 1816 is also listed in Tables 3 and 5 because remarkable extremes occurred in Switzerland and north-eastern France, but not in the Vienna region.

As to the wine failure in the last two decades of the 16th century all over Central Europe, Landsteiner (1999) and Löschnig and Stefl (1935) confirm a very difficult period for winegrowers, and their notes correlate well with information from the towns Litomerice and Zidlochovice. In Puntschert (1894), no information about wine can be found between 1572 and 1599, which is to some extent an indication of an unfavourable time period. The only 2 years which bunch out positively in all records are 1590 and 1599, which-due to two phenological extremes every yearare also listed in Tables 2 and 4.

\subsection{Restrictions and GHD as proxy for temperature extremes}

Since GHD as well as the significantly correlated April to July mean temperatures are existent, the exclusiveness of the given years refers to spring to (early) summer temperature conditions. Another restriction comes from gaps in the Vienna and Klosterneuburg phenological data, which are missing completely from 1880 to 1959 . The year 1740, for example, which is pictured by Löschnig and Stefl (1935) as well as by Puntschert (1894) as a year with a severe winter, cold summer and wine which could not even be converted to vinegar, is not included in our list of extreme years, since we were able to verify an extreme only for Burgundy. In the Vienna region (Vienna-Buergerspital and Klosterneuburg), GHD simply were not recorded, perhaps merely because the vintage was so bad. Furthermore, as the sensitivity of individual grape varieties to temperature means in the vegetation period differs, GHD not consistently derived from one variety every year may give a falsified picture of amplitudes in extreme years. However, for the Vienna region, there is no information about vine varieties except for the "modern" instrumental period in Klosterneuburg, and a change of varieties is bound to occur during a period of several centuries.

These limitations are strengthened by the fact that GHD are the result of somehow subjective decisions, a drawback of this kind of data noted by, e.g. Chuine et al. 
(2004), Meier et al. (2007), Rutishauser et al. (2008) and Leijonhufvud et al. $(2008,2010)$. Rainy weather conditions, social traditions, commercial decisions or warfare give rise to uncertainties, which can hardly be assessed. Therefore, strictly natural information, like flowering data, have to be distinguished from culturally influenced information, like harvest date or wine quantity (Brázdil et al. 2008).

Looking at the pre-instrumental period, we evaluated 19\% accordance with CEuT-AMJJ extremes for outstanding Buergerspital-Vienna GHD, 38\% accordance for outstanding Swiss Plateau Region GHD and 33\% accordance for outstanding Burgundy GHD. Turning to the extreme years in the instrumental period, we found that in $31 \%$ of the given years (with both kinds of data available), an extreme harvest date at Klosterneuburg occurred together with a corresponding AMJJtemperature extreme recorded at Vienna-Hohe Warte. The analogous numbers for the Swiss Plateau Region GHD/ Basel\&Geneva-AMJJ temperatures and Burgundy GHD/ Strasbourg-AMJJ temperatures add up to $43 \%$ and $33 \%$. So, in general, the accordance is not overwhelming, but interestingly, the values for the Swiss Plateau Region are in both periods superior to the ones for Burgundy, which are again superior to the ones reached in the Vienna region.

Pertaining to the temperature reconstructions of Casty et al. (2005) and Etien et al. (2008), an agreement with our extreme year evaluation can be found in $27 \%$ and $31 \%$ of possible years, i.e. extreme years according to our criteria, where a respective temperature reconstruction is available and also yields an outstanding value.

One reason for the lack of accordance is that phenological data are not perfectly correlated to temperature. For example, the year 1837 exhibits several (only two of them are shown in Table 3) quite remarkable negative mean temperature extremes but no outstanding positive GHD. However, there are other reasons too for this lack of correlation. We have to bear in mind that simply the choice of the threshold $2 \sigma$ and/or the observation made only in one or some selected vineyards gives rise to missing extremes. According to Battipaglia et al. (2010), a lack of a common climate signal has to be partly attributed to identifying extremes on the basis of thresholds, where in our case, a $\sigma$ value of 1.9 makes a year ordinary with regard to climate and/or phenology. Besides, summer weather patterns show less coherence than the ones for winter, due to a major influence of local radiation.

\subsection{Problems of inhomogeneity in the "modern"} instrumental period

The delays in the grape harvest in the Vienna region in 1980 look record breaking, though a previous work (Maurer et al. 2009) indicated that a change in vinification took place, at least in the Vienna region. This means facing an extraordinary inhomogeneity regarding the "modern" instrumental period, which-given only one fragmentary time series for the Vienna region-is not quantifiable. Changes in viticultural practices and/or grape varieties have to be held responsible for a slowly developing inhomogeneity in GHD. When using the same reference periods (1545-1649 for Vienna and 1775-1879 for Klosterneuburg), a greater magnitude and a more frequent occurrence of positive GHD extremes are probable. Therefore, harvest extremes for Vienna and Klosterneuburg in $1980(+22.0$ and +25.0 days) are clearly an overestimation, and those for Klosterneuburg in 2003 (-19.0 days) and 2007 (-19.0 days), an underestimation, which becomes evident when comparing them to the harvest data of Burgundy and the Swiss Plateau region (see Table 3). On the other hand, the more extreme values of Burgundy and the Swiss Plateau Region in 2003 are comprehensible because the core of the estival high was located west of Austria.

For the year 1980, no outstanding negative mean temperature extremes can be found at Vienna-Hohe Warte. Nevertheless, the Rasser chronicle (2010) for Gumpoldskirchen reports that the viticultural cycle in this year was delayed by about 8 days in May and by about 10 days in August. June proved to be cool and sometimes rainy. Grapes ripened rather slowly, and their quantity was reduced by $20-30 \%$ compared to that of the previous year.

\subsection{Contradictory information}

For 1571, Löschnig and Stefl (1935, see Table 4) information about wine quality and quantity disagrees with the fact that the grape harvest at the Vienna-Buergerspital, as in the Swiss Plateau Region, was significantly advanced. So, the question arises if the information offered by the chronicle for that year is wrong or is valid for another location (see Section 2.3). The accounts of the Retz Buergerspital to a certain degree confirm the information given in Löschnig and Stefl (1935), insofar as the wine produced was less than in other years (e.g. 1569, 244 buckets; 1570, 147; 1571, 147; 1572, 200).

In 1666, the accounts of the Retz Buergerspital do not confirm the information given in Löschnig and Stefl (1935, see Table 4) of much and very good wine, insofar as the wine produced in 1666 (51 buckets $=2,9581)$ was less than, e.g. in the year 1664 (130 buckets=7,540 1). There is no information in Puntschert (1894).

The year of 1816 has a special character because there seems to be no correlation between extremes, as far as they are defined in the way described in Chapter 3, on a larger interregional scale. However, this special character must be seen in the context of the eruption of the Tombora in April 1815 together with a weak sun-spot maximum during 1816 (Milham 1924), which caused individual cold spells during summer (June to August). Burgundy and the Swiss Plateau Region experienced 
the latest harvest ever since, and corresponding negative AMJJ-mean temperature extremes occurred at Basel\&Geneva and at Strasbourg. Against all expectations, we have got no entries for the region of (mean temperature extremes) and around (phenological records) Vienna in Table 3. It should be noted that Pfister (1999) compares 1816 to 1675, where, according to Table 2, the harvest at the Vienna-Buergerspital was delayed, as in the Swiss Plateau Region.

Contradictory descriptive information on a small regional scale (e.g. 1645 and 1684, Puntschert 1894 versus Löschnig and Stefl 1935) is rare, but it occurs and may be expected, due to local influences and errors made in transcriptions. Besides, the latter compilation-as said before (see Section 2.3)-also relies on German sources and is thus not always relevant for the wine history of Retz. Clearly, compilations often contain misinterpretations or copying mistakes, but primary sources may also be biassed from different causes. Thus, Puntschert (1894) for the year 1684 spoke of a bad wine year and of little wine, in contrast to Löschnig and Stefl (1935) who recorded anomalous heat and drought and an early, rich harvest of very good wine. Therefore, original sources like the accounts of the Retz Buergerspital can be of great value in order to verify the information in the chronicles written later. For 1684, they report a rather meagre harvest of 60 buckets in Retz, which supports the description given by Puntschert (1894).

Acknowledgements We are grateful to Isabelle Chuine, Thomas Dammelhart (Stadtarchiv Retz), Johannes Friedberger (Höhere Bundeslehranstalt für Wein und Obstbau), Karl Holubar (Stiftsarchiv Klosterneuburg), Erich Landsteiner, Günter Müller, Petr Dobrovolný, Rudolf Brázdil and This Rutishauser for giving support and providing valuable suggestions. The BACCHUS II project was funded by the Austrian Federal Ministry of Science and Research and by ZAMG, the Austrian national meteorological service, to whom we also want to express our thanks.

Open Access This article is distributed under the terms of the Creative Commons Attribution Noncommercial License which permits any noncommercial use, distribution, and reproduction in any medium, provided the original author(s) and source are credited.

\section{References}

Apeldauer V (1933) Memorial book of the town Retz [Gedenkbuch der Stadt Retz] Retz

Auer I et al (2007) HISTALP—historical instrumental climatological surface time series of the greater Alpine region 1760-2003. Int J Climatol 27:17-46. doi:10.1002/joc.1377

Battipaglia G, Frank D, Büntgen U, Dobrovolný P, Brázdil R, Pfister C, Esper J (2010) Five centuries of Central European temperature extremes reconstructed from tree-ring density and documentary evidence. Glob Planet Change 72:182-191. doi:10.1016/ j.gloplacha.2010.02.004

Böhm R, Jones PD, Hiebl J, Frank D, Brunetti M, Maugeri M (2010) The early instrumental warm-bias: a solution for long central
European temperature series 1760-2007. Clim Change 101:4167. doi:10.1007/s10584-009-9649-4

Brázdil R, Kotyza O (2000) History of weather and climate in the Czech lands IV. Masaryk University, Brno, Utilisation of economic sources for the study of climate fluctuation in the Louny Region in the fifteenth-seventeenth centuries, $350 \mathrm{pp}$

Brázdil R, Zahradnícek P, Dobrovolný P, Kotyza O, Valásek H (2008) Historical and recent viticulture as a source of climatological knowledge in the Czech Republic. Geografie 113(4):351-371

Brázdil R, Dobrovolný P, Luterbacher J, Moberg A, Pfister C, Wheeler D, Zorita E (2010) European climate of the past 500 years: new challenges for historical climatology. Clim Change 101:7-40. doi:10.1007/s10584-009-9783-Z

Briffa KR, Jones PD, Bartholin TS, Eckstein D, Schweingruber FH, Karlén W, Zetterberg P, Eronen M (1992a) Fennoscandian summers from AD 500: temperature changes on short and long timescales. Clim Dynam 7:111-119

Briffa KR, Jones PD, Schweingruber FH (1992b) Tree-ring density reconstructions of summer temperature patterns across Western North America since 1600. J Climate 5(7):735-754. doi:10.1175/1520-0442

Briffa KR, Jones PD, Schweingruber FH (1994) Summer temperatures across northern North America: regional reconstructions from 1760 using tree-ring densities. J Geophys Res 25:835-844

Büntgen U, Frank DC, Nievergelt D, Esper J (2006) Summer temperature variations in the European Alps, A.D. 755-2004. J Climate 19:5606-5623. doi:10.1175/JCLI3917.1

Büntgen U, Frank DC, Kaczka RJ, Verstege A, Zwijacz-Kozica T, Esper J (2007) Growth/climate response of a multi-species treering network in the Western Carpathian Tatra Mountains, Poland and Slovakia. Tree Physiol 27:689-702

Casty C, Wanner H, Luterbacher J, Esper J, Böhm R (2005) Temperature and precipitation variability in the European Alps since 1500. Int $\mathrm{J}$ Climatol 25(14):1855-1880. doi:10.1002/joc.1216

Chuine I, Yiou P, Viovy N et al (2004) Historical phenology: grape ripening as a climate indicator. Nature 432:289-290. doi:10.1033/432289a

d'Elvert C (1861) Chronicle of the royal town Iglau (1402-1607) by Iglau's town clerk Martin Leupold von Löwenthal. [Chronik der königlichen Stadt Iglau (1402-1607) vom Iglauer Stadtschreiber Martin Leupold von Löwenthal]

Dobrovolný P et al (2010) Monthly, seasonal and annual temperature reconstructions for Central Europe derived from documentary evidence and instrumental records since AD 1500. Clim Change 101:69-107. doi:10.1007/s10584-009-9724-x

Etien N, Daux V, Masson-Delmotte V, Stievenard M, Bernard V, Durost S, Guillemin MT, Mestre O, Pierre M (2008) A bi-proxy reconstruction of Fontainebleau (France) growing season temperature from A.D. 1596 to 2000. Clim Past 4:1-16

Frank D, Esper J (2005) Characterization and climate response patterns of a high elevation, multi-species tree-ring network for the European Alps. Dendrochronologia 22(2):107-121. doi:10.1016/j.dendro.2005.02.004

Garnier E, Daux V, Yiou P, García de Cortázar-Atauri I (2010) Grapevine harvest data in Besancon (France) between 1525 and 1847: social outcomes or climate evidence? Clim Change. doi:10.1007/s10584010-9810-0

Glaser R, Brázdil R, Pfister C, Dobrovolný P, Barriendos Vallvé M, Bokwa A, Camuffo D, Kotyza O, Limanówka D, Rácz L, Rodrigo FS (1999) Seasonal temperature and precipitation fluctuations in selected parts of Europe during the sixteenth century. Clim Change 43(1):169-200. doi:10.1023/A:1005542200040

Jones PD, Briffa KR (2006) Unusual climate in Northwest Europe during the period 1730 To 1745 based on instrumental and documentary data. Clim Change. doi:10.1007/s10584-006-9078-6

Jones PD et al (2009) High-resolution palaeoclimatology of the last millennium: a review of current status and future prospects. Holocene 19(1):3-49. doi:10.1177/0959683608098952 
Landsteiner E (1999) The crisis of wine production in late sixteenthcentury Central Europe: climatic causes and economic consequences. Clim Change 43:323-334. doi:10.1023/A:1005590115970

Lauscher F (1978) New analyses of oldest and more recent phenological time series. [Neue Analysen ältester und neuerer phänologischer Reihen]. Arch Met Geoph Biokl B 26:373-385

Le Roy Ladurie E (1977) The history of sunshine and rainy weather. [Die Geschichte von Sonnenschein und Regenwetter.] In: Honegger C, Bloch M (eds) Script and material of history-proposals for a systematic acquisition of historic processes. [Schrift und Materie der Geschichte-Vorschläge zur systematischen Aneignung historischer Prozesse.] Frankfurt a M, pp 220-240

Leijonhufvud L, Wilson R, Moberg A (2008) Documentary data provide evidence of Stockholm average winter to spring temperatures in the eighteenth and nineteenth centuries. Holocene 18 (2):333-343. doi:10.1177/0959683607086770

Leijonhufvud L, Wilson R, Moberg A, Söderberg J, Retsö D, Söderlind U (2010) Five centuries of Stockholm winter/spring temperatures reconstructed from documentary evidence and instrumental observations. Clim Change 101(1-2):109-141. doi:10.1007/s10584-009-9650-y

Löschnig J, Stefl L (1935) Historical records of the town of Retz. [Geschichtliche Aufzeichnungen der Stadt Retz.] Österreichischer Wein- und Obstbaukalender, pp 149-179

Luterbacher J, Dietrich D, Xoplaki E, Grosjean M, Wanner H (2004) European seasonal and annual temperature variability, trends and extremes since 1500. Science 303:1499-1503. doi:10.1126/ science. 1093877

Luterbacher J, Liniger MA, Menzel A, Estrella N, Della-Marta PM, Pfister C, Rutishauser T, Xoplaki E (2007) The exceptional European warmth of autumn 2006 and winter 2007: historical context, the underlying dynamics and its phenological impacts. Geophys Res Lett 34:L12704. doi:10.1029/2007GL029951

Manley G (1958) The great winter of 1740. Weather 13:11-17

Manley G (1974) Central England temperatures: monthly means 1659 to 1973. Q J Roy Meteorol Soc 100:389-405

Margary ID (1926) The Marsham phenological record in Norfolk 1736-1925, and some others. Q J Roy Meteorol Soc 52:27-54

Maurer C, Koch E, Hammerl C, Hammerl T, Pokorny E (2009) BACCHUS temperature reconstruction for the period 16th to 18th centuries from Viennese and Klosterneuburg grape harvest data. J Geophys Res 114:D22106. doi:10.1029/2009JD011730

Meier N, Rutishauser T, Pfister C, Wanner H, Luterbacher J (2007) Grape harvest data as a proxy for Swiss April to August temperature reconstruction back to A.D. 1480. Geophys Res Lett 34:L20705. doi:10.1029/2007GL031381

Menzel A (2005) A 500 year pheno-climatological view on the 2003 heat wave in Europe assessed by grape harvest data. Meteorol Z 14(1):75-77. doi:10.1127/0941-2948/2005/0014-0075

Milham WI (1924) The year 1816-the causes of abnormalities. Mon Weather Rev 52(12):563-570

Pfister C (1985) History of the climate of Switzerland 1525-1860. The climate of Switzerland from 1525 to 1860 and its relevance in the history of population and agriculture, Volume 1. [Klimageschichte der Schweiz 1525-1860. Das Klima der Schweiz von 1525-1860 und seine Bedeutung in der Geschichte von Bevölkerung und Landwirtschaft, Band I.] Academica Helvetica, Bern, 184 pp

Pfister C (1999) Weather hindcast. 500 years of climate variability and natural disasters 1496-1995. [Wetternachhersage. 500 Jahre Klimavariationen und Naturkatastrophen 1496-1995.] Verlag Paul Haupt, Bern, 304 pp

Pfister C, Brázdil R (2006) Social vulnerability to climate in the "Little Ice Age": an example from Central Europe in the early 1770 s. Clim Past 2:123-155

Pilgram A (1788) Investigations of what is probable in meteorology through perennial observations. [Untersuchungen über das
Wahrscheinliche der Wetterkunde durch vieljährige Beobachtungen] Joseph Edlen von Kurzbeck, k.k. Hofbuchdrucker, Wien

Pribram AF, Geyer R, Koran F (1938) Materials regarding the history of prices and wages in Austria, Volume 1. [Materialien zur Geschichte der Preise und Löhne in Österreich, Vol. 1.] Carl Ueberreuters Verlag, Wien

Puntschert JK (1894) Memorabilities of the town of Retz. [Denkwürdigkeiten der Stadt Retz.] Selbstverlag der Stadt Retz, Wien

Rutishauser T, Luterbacher J, Jeanneret F, Pfister C, Wanner H (2007) A phenology-based reconstruction of interannual changes in past spring seasons. J Geophys Res 112:G04016. doi:10.1029/ 2006JG000382

Rutishauser T, Luterbacher J, Defila C, Frank D, Wanner H (2008) Swiss spring plant phenology 2007: extremes, a multi-century perspective, and changes in temperature sensitivity. Geophys Res Lett 35:L05703. doi:10.1029/2007GL032545

Sammlung (1719) Compilation of histories of nature and medicine - as well as histories pertinent hereto of art and literature. $4^{\text {th }}$ attempt. [Sammlung von Natur und Medicin-Wie auch hierzu gehörigen Kunst- und Literaturgeschichten. 4. Versuch] Michael Hubert, Breslau

Sandgruber R (1995) Economy and politics. Economic history of Austria from the Middle Ages to the present. [Ökonomie und Politik. Österreichische Wirtschaftsgeschichte vom Mittelalter bis zur Gegenwart.] In: Wolfram H (ed.) History of Austria, Volume 10 [Österreichische Geschichte, Bd. 10], 669 pp

Sommer M (2008) Résumé of the characteristics of an analysis of authentic wines of different vintages and their viticulturalclimatic interpretation. Diploma thesis in the disciplines chemistry of fruits and fruit products. [Zusammenfassung der Analysenkenndaten von authentischen Weinen verschiedener Jahrgänge und deren weinbaulich-klimatische Interpretation. Diplomarbeit aus den Fachgegenständen Chemie der Früchte und Fruchtprodukte.] Mathematik, Lehr- und Forschungszentrum für Wein- und Obstbau, Klosterneuburg, Austria

Sparks TH (2007) Lateral thinking on data to identify climate impacts. Trends Ecol Evol 22(4):169-171

Strestik J, Verö J (2000) Reconstruction of the spring temperatures in the 18th century based on the measured lengths of grapevine sprouts. Q J Hungarian Meteorol Serv Idöjárás 104(2):123-136

Versuch (1803) Attempt of a centennial history of vinification in Austria; from 1700 to 1800 from primary sources. [Versuch einer hundertjährigen Weinfechsungsgeschichte Österreichs; von 1700 bis 1800 aus Urquellen] Schmidbauer, Wien

\section{Archival sources}

News from Klosterneuburg 2000. [Mitteilungen Klosterneuburg 2000]

Rasser chronicle (2010) Manuscript, recordings of Rudolf and Franz Rasser, Gumpoldskirchen, private property. [Rasser Chronik (2010), Manuskript, Aufzeichnungen von Rudolf und Franz Rasser, Gumpoldskirchen, Privatbesitz]

Schmuckenschlager B (2007) Grape harvest data Agneshof Klosterneuburg. [Lesedaten Agneshof Klosterneuburg.] (manuscript)

StAK(losterneuburg) MS 121: Bittmann J (1880) Memorial book and wine chronicle [Gedenkbuch und Weinchronik]

StAK MS 102

StAK MS 122/1

StAK MS 122/2

StAK D 73

StAK Box 221 (Chronicle of weather and contingencies [Wetter und Zufällechronik], compiled by Willibald Leyrer in 1789)

StARetz, Accounts of Buergerspital [Buergerspitalrechnungen] 15271860 